\title{
KOSDAQ IPO Firms' Advertising Expenditures and Stock Returns
}

\author{
Jee-Hyun Kim11), Nam-Gon Kim²)
}

\begin{abstract}
This article provides evidence of the influence of the advertising expenditure of a firm going public on the initial public offering (IPO) underpricing. It is found that a higher level of advertising expenditure is associated with a lesser extent of IPO underpricing with the help of the positive signaling effect regarding the issuing firm. Because advertising expenditure is a commonly used proxy for marketing cost in the value-relevant marketing research domain, the results of this study also highlighted the effect of marketing decision in financial markets, beyond its direct effect on the sales and profits. The empirical evidence indicates that the marketing decisions, specifically advertising expenditures, are closely related with the shareholder value, especially in the context of a firm going public.
\end{abstract}

Keywords : KOSDAQ, IPO, Advertising Expenditures, Abnormal Return, Stock

\section{Introduction}

This paper seeks the link between the advertising expenditures and the intial public offering underpricing of the firms going public. According to the previous literature, the advertising expenditures appears to have a positive influence on the market value of the firm[1-4]. The potential shareholders make their investment decision based on the expectation concerning the future cash flows. The spending on advertising help these investors to have an appropriate expectation on the size and quality of future cash flows, leading to a decreased information asymmetry between the stock market investors (outsiders) and firm managers (insiders)[5-9]. The firm managers make decisions strategically concerning their resource allocation to maximize the long-term value of equity, which is, equivalently, the present value of expected future cash flows[10-16].

On the other hand, one of the pivotal events of a firm to enhance its value is the going public decision. A firm can raise needed capital through the issue of new equity acquired by external investors. Because internal capital may not be adequate to cover the value-increasing projects with

Received(September 22, 2017), Review Result(1st: October 16, 2017, 2nd: November 30, 2017), Accepted(December 10, 2017)

1) (Student) Dept. Business Administration, Hallym Univ., Chuncheon-si, Gangwon-do, 24252, Korea email: jhyunkim@hallym.ac.kr

2) (Professor, Corresponding Author) Dept. Business Administration, Dongduk Women's Univ., Wolgok-dong, Sungbuk-gu, Seoul, 02748, Korea

email: fencer@dongduk.ac.kr 
high growth of opportunity, raising capital from external investors is critical for the increase of the firm value. Notwithstanding the benefits of going public, the existence of information asymmetry between a firm issuing new equity and external investors generate the underpricing of initial public offerings (Beatty and Ritter, 1986; Rock, 1986; Carter and Manaster, 1990)[14-18].

The underpricing of initial public offerings (IPOs) is the phenomenon that the offer price is less than its fundamental value, leading to the abnormal positive return on the first day of the issue. The IPO underpricing, a well-known puzzle in the financial market, is widely studied in the financial academia. A large body of research explains the IPO underpricing puzzle based on the signaling hypothesis, arguing that the IPO underpricing stems from asymmetric information between outsiders and insiders of the IPO firm. Compared to the insiders having superior information about the true value of the firm, external investors are in a less informed position. Therefore, the potential investors ask the compensation for taking uncertainty and spending costs in collecting information, via a substantial discount in the IPO price. This argument suggests that when there is a lower degree of uncertainty, we may observe the reduced IPO underpricing[19-20].

Combining the signaling role of advertising in stock market and the reasons for the IPO underpricing, we can expect that the advertising expenditure can play a role in the IPO underpricing. If advertising expenditure spent by a firm going public convey a fundamental signal to the equity market investors with respect to future cash flows of the firm, it may mitigate the asymmetric information, and, therefore, the extent of the IPO underpricing.

The purpose of this paper is to investigate how the advertising expenditures of a firm undertaking initial public offerings affect the IPO underpricing. A large body of studies have devoted attention to the effect of advertising expenditure on the firm value and to the factors affecting the IPO underpricing puzzle in the context of signaling theory, separately. However, the link between the advertising expenditures and the IPO underpricing has not been analyzed so far in the literature.

Using the initial public offering cases in the KOSDAQ market from 2011 to 2015, we find the strong evidence that advertising expenditures play a role as signals for external investors and financial markets by reducing the extent of the underpricing phenomenon in the IPOs. It is highlighted that the higher level of advertising expenditures lead to a less pronounced IPO underpricing.

The remainder of this paper is organized as follows. Section 2 provides previous literature with respect to the advertising expenditures and the IPO underpricing. In Section 3, after describing the data and research models employed for the analysis of the link between advertising and expenditure, the empirical results were discussed. Section 4 concludes the paper. 


\section{Literature Review}

\subsection{Advertising expenditures and the firm value}

The extant literature in the area of marketing, finance, and accounting argue that the spending on advertising may have a direct and/or indirect influence on the firm's intrinsic value. In a direct way, the advertising expenditures convey positive signals to external investors that the company has the financial ability to distribute their resource in enhancing the satisfaction of original customers and attracting new potential customers. These effects are beyond the indirect influence of advertising such as increase of sales revenue or profits. (Joshi and Hanssens 2009, 2010). In addition, according to McAlister, et al. (2007), the advertising creates a barrier to competition, which can increase bargaining power towards distributors and can provide the efficiency and flexibility in environmental changes.

The existing evidence regarding the effect of advertising expenditures on firm value, however, is at best, mixed. Conchar, et al. (2005), after the meta-analysis, find the insignificant relationship between the level of advertising and the market value of the firm, which have a wide range between -5.98 and 9.50. Conchar, Crask, and Zinkhan (2005) report an insignificant relationship between advertising and firm value. Kim and McAlister(2011) report that the stock market reaction can be different according to various proxy for expenditures for marketing.

If advertising expenditure play a positive role for the market value of a firm, it would convey a positive fundamental signal to the equity market investors with respect to the future cash flows of the firm. Grullon, Kanatas, and Weston (2004) show that a high level of spending on advertising is positively associated with the reduction in adverse selection stemming from information asymmetry.

After empirical tests using various proxy for resource allocation decisions at the time of the IPO, including R\&D expenditures, capital investments, and advertising expenditures, Jain and Kini (2008) document that they could not find any evidence that the advertising intensity enhances the long-run performance of the firm.

\subsection{Underpricing of the Initial Public Offering}

The firm facing the IPO decides in the going public process, not only the amount of the capital to be raised from the external public investors, but also the offer price of the listing stock. To successfully conduct the IPO process, the issue price of the equity is decided at lower level than the firm's fundamental value. Researchers have devoted much effort to explain this IPO underpricing 
phenomenon, called "the IPO underpricing puzzle."

Since Stoll and Curley (1970), Logue (1973), and Ibbotson (1975) find that the closing price of the first day of IPO firms systematically increase from their offer price, a large body of studies have tried, empirically and theoretically, to explain the reason for this IPO underpricing phenomenon.

One of the well-known related theory is the signaling model, proposed by Welch (1989). The important underlying assumption in this model is that insiders of the IPO firm have superior information to external stock market participants. According to Rock (1986), the adverse selection form information asymmetry between insiders and outsiders of the firm generate cost for uninformed outsiders to collect information regarding the issuing firm. IPO underpricing, therefore, can be considered as compensation for this extra cost of outsiders. Ritter(1984), Beatty and Ritter(1986), Carter and Manaster, 1990, and Daily, et al. (2005) also argue that external investors collect information to mitigate the uncertainty existing around the fundamental value of a firm. Certo, et al. (2001, 2009), Daily, et al.(2003), among others, also investigate the IPO underpricing in the context of the quality signals.

While the previous literature has focused on the determinant affecting the IPO underpricing, scant attention has been paid to the role of advertising expenditures even though it can affect the information asymmetry between the firm managers and external investors and, therefore, can possibly reduce the IPO underpricing.

\section{Empirical Results}

[Table 1] shows the annual breakdown of IPOs in Korea between 2011 and 2015. This table reports the increasing number of firms that went public after 2012. While 20 firms went public in 2012, the number increased to 57 in 2015.

[Table 1] IPO in the KOSDAQ Market

\begin{tabular}{|c|c|c|}
\hline Year & Number of firms & portion (\%) \\
\hline 2011 & 55 & 26.69 \\
2012 & 20 & 9.71 \\
2013 & 34 & 16.51 \\
2014 & 40 & 19.42 \\
2015 & 57 & 27.67 \\
\hline Total & 206 & 100.00 \\
\hline
\end{tabular}

To examine the effect of advertising expenditure on IPO underpricing, following the IPO literature, we employ the event study methodology. For analyzing these relationship, we first examine whether 
there exists the IPO underpricing in our sample covering the period from 2011 to 2015 , by testing the short term performance of the IPO firms.

The abnormal return (AR) and cumulative abnormal return (CAR) were calculated. To compute the abnormal return of the day $t$, which is the realized return minus the normal return, the normal return is defined as the market return of day $t$. Considering that the sample is based on the IPO cases in the KOSDAQ market, the KOSDAQ market return is employed. The abnormal return of the first trading day can measure the IPO underpricing: the higher level of the abnormal return is associated with the larger degree of the underpricing. The first-day return, Rit, is then calculated by dividing the difference between the offer price and the closing price of the first trading day after the IPO.

$$
R_{t} \quad R_{i t}-R_{m t}
$$

Here,

$R_{i t} \quad:$ return on firm $\mathrm{i}$ on day $\mathrm{t}$

$R_{m t} \quad$ : return on a market portfolio on day $\mathrm{t}$

Since there are multiple initial public offerings, the average abnormal return (AAR) is calculated by the following formula.

$$
\begin{aligned}
& A A R_{t}={ }_{N_{i=1}}^{1} A R_{i t}, \\
& A R_{\text {it }} \quad \text { : abnormal return on firm } \mathrm{i} \text { on day } \mathrm{t} \\
& N \quad \text { : number of firms }
\end{aligned}
$$

Cumulative returns and averaged cumulative returns can be calculated once the abnormal and the average abnormal returns are obtained as follows.

$$
\begin{aligned}
& C A R_{t 1, t 2}=\sum_{t=-t 1}^{t 2} A R_{t} \\
& C A A R_{t 1, t 2}=\sum_{t=-t 1}^{t 2} A A R_{t}
\end{aligned}
$$

Here,

$$
\begin{array}{ll}
A R_{t} & : \text { abnormal return on day } \mathrm{t} \\
A A R_{t} & : \text { average abnormal return on day } \mathrm{t}
\end{array}
$$

A large body of previous studies argue that the substantial information asymmetry between firm managers (firm insiders) and external investors can induce underpricing of the firm's equity in its IPO (Beatty and Ritter, 1986; Rock, 1986; Carter and Manaster, 1990). 
For the first analysis, the IPO underpricing phenomenon is examined whether it exists in the Korean stock market. IPO underpricing is typically measured by the first-day return of the newly issued stock. [Table 1] provides the results of the event study analysis. [Table 1] and [Figure 1] provide the results.

According to [Table 2], IPO firms experience large initial returns on the first trading day after going public, suggesting the issue price is lower than its intrinsic value. The first-day return of newly listed stock in the sample is, on average, 36.85 percent and this value is statistically significant at the $1 \%$ level. This empirical results show that the IPO underpricing is severe in Korea, compared to the average 18 percent of IPO underpricing in the US stock market (Ritter and Welch, 2002).

[Table 2] Abnormal Returns and Cumulative Abnormal Returns on the IPO Firms in the KOSDAQ Market

\begin{tabular}{|c|c|c|c|c|c|c|}
\hline & \multicolumn{3}{|c}{ AR(AbnormalReturn) } & \multicolumn{3}{c|}{ CAR } \\
\hline Days & AAR & Std. of AR & T-Value & CAAR & Std. of CAR & T-Value \\
\hline 0 & 0.36849 & 0.4530727 & $\begin{array}{c}11.3539^{* *} \\
*\end{array}$ & 0.36849 & 0.4530727 & $11.3539^{* * *}$ \\
\hline 1 & -0.00788525 & 0.0948687 & -1.1539 & 0.3606054 & 0.47328249 & $10.5233^{* * *}$ \\
\hline 2 & -0.00515816 & 0.0869216 & -0.8256 & 0.3552664 & 0.50918283 & $9.7430^{* * *}$ \\
\hline 3 & -0.00533898 & 0.0644107 & -1.1203 & 0.3497054 & 0.52258249 & $9.4833^{* * *}$ \\
\hline 4 & -0.00298727 & 0.0577616 & -0.7182 & 0.3462926 & 0.53119392 & $9.5546^{* * *}$ \\
\hline 5 & -0.00758628 & 0.0552774 & $-1.8679^{*}$ & 0.3320779 & 0.53290302 & $8.8697^{* * *}$ \\
\hline 10 & -0.00733551 & 0.0558379 & $-1.8651^{*}$ & 0.3326442 & 0.54626952 & $8.5599^{* * *}$ \\
\hline 20 & 0.00388103 & 0.0467183 & 1.1737 & 0.3441979 & 0.53906595 & $8.7280^{* * *}$ \\
\hline 30 & -0.0029274 & 0.0407639 & -1.01409 & 0.3656887 & 0.52152877 & $9.6337^{* * *}$ \\
\hline
\end{tabular}

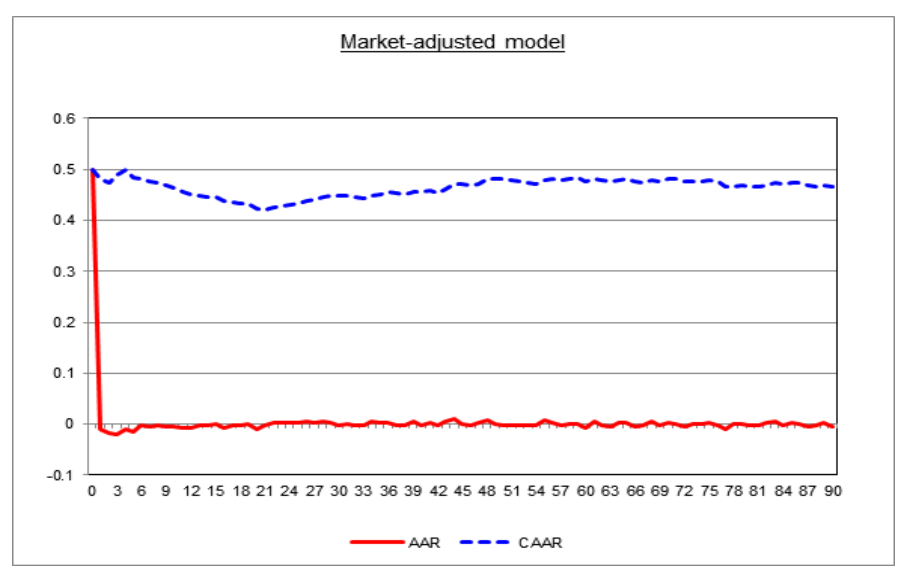

[Fig. 1] Abnormal Returns and Cumulative Abnormal Returns on the IPO firms in the KOSDAQ market

Additionally, the short-term performance of IPOs are provided in [Table 1], by reporting the cumulative abnormal returns in 30 days after the issue date. Figure 1 depicts the abnormal returns 
and the cumulative abnormal returns (CAR) of IPO firms up to 90 days after the issue of new equity. It can be seen that after experiencing the decrease of CAR in the beginning, the CAR of IPO firms rebound and get stable in about 30 days after the stock is listed. The reduction of CARs in the beginning occurs because the abnormal returns following days are lower than the first-day return, suggesting the extraordinarily high level of the return on the first trading day due to the IPO underpricing.

Given the existence of the IPO underpricing phenomenon in the Korean stock market, the attention is focused on the link between the advertising expenditures and the extent of the IPO underpricing. For this analysis, the following regression model is being run.

Model 1: $\quad R \quad \alpha+\beta \times \ln b i d_{i}+\epsilon_{i}$

Model 2: $A R_{i}=\alpha+\beta_{1} \times \ln b i d_{i}+\beta_{2} \times \ln$ size $_{i}+\epsilon_{i}$

Model 3: $A R_{i}=\alpha+\beta_{1} \times \ln b i d_{i}+\beta_{2} \times \ln s_{i z e_{i}}+\beta_{3} a d v_{i}+\beta_{4} a d v b i d_{i}+\epsilon_{i}$

Here,

$\begin{array}{ll}\mathrm{AR}_{i} & : \text { Abnormal return for firm } \mathrm{i} \text { on the event day } \mathrm{t} \\ \operatorname{lnbid}_{i} & : \text { the natural log of the bid competition of firm } \mathrm{i} \\ \operatorname{lnsize}_{i} & : \text { the natural log of the initial offering size of firm } \mathrm{i} \\ \operatorname{adv}_{i} & : \text { advertising expenditures scaled by total sales of firm } \mathrm{i} \\ \operatorname{advbid}_{i} & : \text { advi } \cdot \text { lnbidi (interaction term of adv and lnbid) }\end{array}$

The dependent variable in this model is the abnormal return on the first trading day, which measures the IPO underpricing. The independent variable, advi, is the level of advertising expenditures which is scaled by total sales. Following the previous studies, control variables are also included which are known to be related with the IPO underpricing (see, Daily, et al., 2003).

[Table 3] The Advertising Expendirue and the IPO Underpricing

\begin{tabular}{|l|l|l|l|}
\hline & \multicolumn{1}{|c|}{ Model 1 } & \multicolumn{1}{c|}{ Model 2 } & \multicolumn{1}{c|}{ Model 3 } \\
\hline Intercept & $-0.15082\left(-2.63^{* * *}\right)$ & $0.18479(0.91)$ & $0.07877(0.34)$ \\
\hline Inbid & $0.09655\left(8.29^{* * *}\right)$ & $0.09175\left(7.36^{* * *}\right)$ & $0.08657\left(4.81^{* * *}\right)$ \\
\hline Insize & & $-0.06169\left(-1.77^{*}\right)$ & $-0.03656(-0.96)$ \\
\hline adv & & & $-25.65462\left(-2.47^{* *}\right)$ \\
\hline advbid & & & $4.27642(2.37 * *)$ \\
\hline Adj R-Sq & 0.1602 & 0.1686 & 0.1692 \\
\hline F value & $38.02^{* * *}$ & $20.67^{* * *}$ & $8.48^{* * *}$ \\
\hline
\end{tabular}

In the third regression equation, Authors regress the abnormal returns on the amount of advertising expenditures, advi, controlling for the other variables, including the bid competition and 
initial offering size. [Table 3] presents the results of models 1 through 3 from the analysis of regressions.

The results in Column 3 suggest that firms with a higher level of advertising expenditures shows a smaller level of IPO underpricing, indicating a smaller amount of information asymmetry. The coefficient of the advertising expenditure, advi, is negative (-25.65) as well as statistically significant at the $5 \%$ level. The coefficient shows that the extent of the underpricing of a firm going public is smaller as the firm insiders decide to spend more on advertising. The result in [Table 3] suggests that the advertising expenditure convey a signal to reduce the information asymmetry between firm insiders and external investors of the IPO firm, and, hence, mitigate the price discount in the IPOs.

\section{Conclusion}

This paper investigates the effect of advertising expenditures on the underpricing phenomenon of the firms at the time of the IPO. Since Welch (1989) proposes a signaling model to explain the IPO underpricing, numerous studies in financial area have tried to find out the factors affecting the underpricing phenomenon in the context of the information asymmetry. However, little attention has been given to the signaling role of advertising, which is intensively studied in the marketing literature, in the IPO market.

It is found that the advertising expenditure of a firm going public has a strong negative relationship with the abnormal return on the IPO date, indicating the smaller underpricing of the new equity.

Because advertising expenditure is a commonly used proxy for marketing cost in the value-relevant marketing research domain, the results of this study also highlight the effect of marketing decision in financial markets, beyond its direct effect on the sales and profits.

\section{References}

[1] Beatty, Randolph P. and Jay R. Ritter, Investment Banking, Reputation, and the Underpricing of Initial Public Offerings, Journal of Financial Economics, (1986), Vol.15, No.(1-2), pp.213-232.

[2] Carter, Richard and Steven Manaster, Initial Public Offerings and Underwriter Reputation, Journal of Finance, (1990), Vol.45, No.4, pp.1045-1067.

[3] Certo, S. Trevis, Jeffrey G. Covin, Catherine M. Daily and Dan R. Dalton, Wealth and the Effects of Founder Management among IPO-Stage New Ventures, Strategic Management Journal, (2001), Vol.22, No.(6-7), pp.641-658. 
[4] Certo, S. Trevis, Tim R. Holcomb and R.Michael Holmes, "IPO Research in Management and Entrepreneurship: Moving the Agenda Forward", Journal of Management 35(6), (2009), pp.1340-1378.

[5] Conchar, Margy P., Melvin R. Crask and Gerorge M. Zinkhan, Market Valuation Models of the Effect of Advertising and Promotional Spending: A Review \& Meta-analysis, Journal of the Academy of Marketing Science, (2005), Vol.33, No.4, pp.445-460.

[6] Daily, Catherine M., S. Trevis Certo, Dan R. Dalton and Rungpen Roengpitya, IPO Underpricing: a Meta-Analysis and Research Synthesis, Theory and Practice, (2003), Vol.2, No.3, pp.271-295.

[7] Daily, Catherine M., S. Trevis Certo and Dan R. Dalton, Investment Bankers and IPO Pricing: Does Prospectus Information Matter?, Journal of Business Venturing, (2005), Vol.20, No.1, pp.93-111.

[8] Grullon, Gustavo, George Kanatas and James P. Weston, Advertising, Breadth of Ownership, and Liquidity, Review of Financial Studies, (2004), Vol.17, No.2, pp.439-461.

[9] Ibbotson, Roger G., Price Performance of Common Stock New Issues, Journal of Financial Economics, (1975), Vol.2, No.3, pp.235-272.

[10] Jain, Bharat A. and Omesh Kini, The Impact of Strategic Investment Choices on Post-Issue Operating Performance and Survival of US IPO Firms, Journal of Business Finance and Accounting, (2008), Vol.35, No.3, pp.459-490.

[11] Joshi, Amit M. and Dominique M. Hanssens, Movie Advertising and the Stock Market Valuation of Studios: A Case of 'Great Expectations?', Marketing Science, (2009), Vol.28, No.2, pp.239-250.

[12] Joshi, Amit M. and Dominique M. Hanssens, The Direct and Indirect Effects of Advertising Spending on Firm Value, Journal of Marketing, (2010), Vol.74, No.1, pp.20-33.

[13] Kim, MinChung and Leigh M. McAlister, Stock Market Reaction to Unexpected Growth in Marketing Expenditure: Negative for Salesforce, Contingent on Spending Level for Advertising, Journal of Marketing, (2011), Vol.75, No.4, pp.68-85.

[14] Logue, Dennis E., On the Pricing of Unseasoned Equity Issues: 1965 -1969, Journal of Financial and Quantitative Analysis, (1973), Vol.8, No.1, pp.91-103.

[15] McAlister, Leigh M., Raji Srinivasan and MinChung Kim, Advertising, Research and Development, and Systematic Risk of the Firm, Journal of Marketing, (2007), Vol.71, No.1, pp.35-48.

[16] Ritter, Jay R., The Hot Issue Market of 1980, Journal of Business, (1984), Vol.57, No.2, pp.215-240.

[17] Ritter, Jay R. and Ivo Welch, A Review of IPO Activity, Pricing, and Allocations, Journal of Finance, (2002), Vol.57, No.4, pp.1795-1828.

[18] Rock, Kevin, Why New Issues are Underpriced, Journal of Financial Economics, (1986), Vol.15, No.(1-2), pp.187-212.

[19] Stoll, Hans R. and Anthony J. Curley, Small Business and the New Issues Market for Equities, Journal of Financial and Quantitative Analysis, (1970), Vol.5, No.3, pp.309-322.

[20] Welch, Ivo, Seasoned Offerings, Imitation Costs, and the Underpricing of Initial Public Offerings, Journal of Finance, (1989), Vol.44, No.2, pp.421-449. 